\title{
Why morphology matters: the negative consequences of hasty descriptions of putative novelties in asexual ascomycetes
}

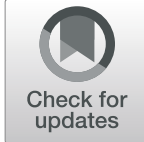

\author{
Ondřej Koukol ${ }^{1 *}$ (D) and Gregorio Delgado ${ }^{2}$
}

\begin{abstract}
Recent progress in the discovery of fungal diversity has been enabled by intensive mycological surveys in centres of global biodiversity. Descriptions of new fungal species have been almost routinely based on phenotypic studies coupled with single or multigene phylogenetic analyses of DNA sequence data. However, high accessibility of sequencing services together with an increasing amount of available molecular data are providing easier and less critical support for taxonomic novelties without carefully studying the phenotype, particularly morphology. As a result, the accelerated rate of species descriptions has been unfortunately accompanied by numerous cases of overlooking previously described and well documented species, some of them that have been known for more than a century. Here, we critically examined recent literature, phenotypic and molecular data, and detected multiple issues with putative novelties of asexual Ascomycota traditionally known as hyphomycetes. In order to fix these taxonomic problems, three new combinations within the genera Pleopunctum, Camposporium and Sporidesmium, and two new names in Camposporium are proposed. Moreover, three genera, Aquidictyomyces, Fusiconidium and Pseudohelminthosporium, together with nine species are reduced to synonymy. The examples outlined here clearly show the relevance of morphology in modern phylogenetic studies and the importance of more stringent 'quality controls' during biodiversity studies documenting the extensive fungal diversity in a speedy manner.
\end{abstract}

KEYWORDS: Five new taxa, Asexual Ascomycota, Dothideomycetes, Sordariomycetes

\section{INTRODUCTION}

In recent years, the attempts to describe the "amazing fungal diversity" and to "flatten the curve" of known fungal species (Hyde et al. 2018, Hyde et al., 2020b) have led to an increased rate in the description of novel fungal taxa, especially in the Paleotropics but particularly in Southeast Asia. According to the 2020 State of the World's Plants and Fungi report (Antonelli et al. 2020), 41\% of species newly described in 2019 originated from Asia due to both an enormous fungal diversity hidden in this part of the world but also thanks to the diligent contribution and sustained efforts of local taxonomists.

\footnotetext{
* Correspondence: ondrej.koukol@natur.cuni.cz

'Department of Botany, Faculty of Science, Charles University, Benátská 2, 12801 Prague, Czech Republic

Full list of author information is available at the end of the article
}

However, not all recent descriptions are well supported by phenotypic and molecular data and many of them are even questionable if not erroneous (Koukol et al. 2020). Here, we present multiple examples of recent issues with putative taxonomic novelties of asexual fungi belonging to Ascomycota traditionally known as hyphomycetes whenever literature records and phenotypic data provide sufficient evidence. Our intention is to call the mycological community involved in conducting fungal diversity studies for a reflection on the necessity of more critical and careful approaches during the introduction and description of novel microfungi. This call is made in the same positive spirit of Gams (2016) or Van Vooren and Vega (2018), for example, and in the best interest of all users of fungal names and the science of Mycology.

(c) The Author(s). 2021 Open Access This article is licensed under a Creative Commons Attribution 4.0 International License, which permits use, sharing, adaptation, distribution and reproduction in any medium or format, as long as you give appropriate credit to the original author(s) and the source, provide a link to the Creative Commons licence, and indicate if changes were made. The images or other third party material in this article are included in the article's Creative Commons licence, unless indicated otherwise in a credit line to the material. If material is not included in the article's Creative Commons licence and your intended use is not permitted by statutory regulation or exceeds the permitted use, you will need to obtain permission directly from the copyright holder. To view a copy of this licence, visit http://creativecommons.org/licenses/by/4.0/. 
Species concepts in Fungi reflect their multiple evolutionary histories, huge diversity of morphology, trophic and reproductive strategies and have both practical and theoretical limitations (Lücking et al. 2020). Hyde et al. (2020b) recently emphasized that in current mycological praxis "we mostly rely on phenotypic and phylogenetic aspects and consider a species as a group of individuals sharing similar phenotypes and sufficient DNA similarities". They further added that these individuals "must be sufficiently distinct from another sister group / species and have ample differences in DNA, supported with phylogeny or other analyses". These simple although critical statements contain crucial assertions that are currently not followed in many studies, e.g., "group of individuals". Although a single individual is extremely difficult if not impossible to define among microfungi, this can be avoided by studying multiple specimens or strains from different collection sites or substrates. However, a large number of asexual taxa in Ascomycota have been recently described based only on a single collection or strain, preventing a proper assessment of their species boundaries or intraspecific variability and the confirmation of taxonomic conclusions. Clearly, independent collections may be difficult to obtain for rare species, but descriptions may be postponed during long-term studies of a particular area or substrate until more specimens or strains become available.

Besides having limited representative material, too much emphasis is often placed on molecular data whereas a detailed study of the morphology together with a thorough review of relevant literature are often neglected. This unfortunate trend may be best viewed from the Notes sections following description of novelties, where sequence similarities are considered first if not the sole distinguishing characters used (Tibpromma et al. 2018). Although recent progress in successfully sequencing fungarium specimens has provided better delimitation of species boundaries even for "old" taxa (Forin et al. 2018), asexual ascomycetes in particular are often lacking reference ex-type sequences for comparison. Additionally, a huge gap in sequence availability for members of several thousand genera currently considered Ascomycota "incertae sedis" still exists (Wijayawardene et al. 2018). Therefore, the knowledge of morphology remains essential for proper delimitation of known species and description of taxonomic novelties (Aime et al. 2021).

\section{TAXONOMY}

\section{Descriptions of recent Hermatomyces species suffer from} inconsistencies

An illustrative example of multiple taxonomic issues is the genus Hermatomyces, which has received much attention in recent years from both the Paleotropics and
Neotropics. Recently, an alarming high number of imprecise species descriptions based on mixed phenotypic and molecular data together with insufficient understanding of previous species delimitations was revealed (Koukol et al. 2018; Koukol and Delgado 2019; Delgado et al. 2020). Six out of the 28 binomial names introduced in Hermatomyces (Index Fungorum http://www. indexfungorum.org/) were found to be later synonyms and other three are considered doubtful or described based on insufficient evidence, which gives an error rate of $32 \%$ of erroneously described species in a single genus. One of the reasons of this high rate is that many recently described species such as $H$. clematidis, $H$. bauhiniae, and $H$. trangensis amongst others, were introduced based on a single or at most two collections from the same site and host. Hermatomyces clematidis, for example, described from a dead stem of Clematis sikkimensis in Thailand (Phukhamsakda et al. 2020) is morphologically identical with Hermatomyces sp. IMI 289491 collected from a dead twig in Ethiopia and recently studied by Koukol and Delgado (2019). A more complete overview on the ecology and the intraspecific variability of this species, for example the intensity of melanization in the apex of cylindrical conidia, would be obtained by a comparison with the African material and its distribution in this continent even in the absence of DNA sequence data. Additionally, hasty introduction of species descriptions has led to mishandling with own data. Delgado et al. (2020), for example, already showed that $H$. bauhiniae was based on a mixed collection and the published morphological description referred to a contaminating fungus. Ironically, the contaminant was described later from Thailand by the same authors in the same year as Pleopunctum clematidis. As Delgado et al. (2020) already suggested, a new combination is necessary to fix this name and therefore the confusing name $H$. bauhiniae is considered superfluous and a new combination is provided herein.

Pleopunctum bauhiniae (Phukhams. et al.) Koukol \& G. Delgado, comb. nov.

MycoBank: MB838824.

Basionym: Hermatomyces bauhiniae Phukhams. et al., Fungal Diversity 96: 40 (2019).

Synonym: Pleopunctum clematidis Phukhams et al., Fungal Diversity 102: 73 (2020).

Description: Hyde et al. (2019).

\section{Canalisporium dehongense and C. thailandense are synonyms}

The hasty description of novel species without critical evaluation of literature has also caused incongruences in the genus Canalisporium. Two species, C. thailandense and C. krabiense, were recently described based on single isolates obtained from leaves of Pandanus sp. in 
Thailand (Tibpromma et al., 2018). Although they differ substantially in morphology, sequences of ITS and LSU rDNA originating from their holotypes and deposited in GenBank are 100 and $99.8 \%$ identical, respectively. Surprisingly, their close position in a single clade in the phylogenetic tree was not commented by Tibpromma et al. (2018). Furthermore, only pairwise identities with sequences already available in GenBank were mentioned but not between the two species. Cross-contamination with DNA of C. krabiense obviouly resulted in identical sequences being connected with different "morphospecies". Once the morphology of $C$. thailandense with its unique "globose to oval conidiogenous cells connected in a chain" is taken into consideration, another species described from China a year later (Hyde et al. 2019) could be considered conspecific. Canalisporium dehongense is characterized by the same chains of vesiculate cells with nearly identical conidial dimensions, but it has a distinct basal position within the Canalisporium lineage (Hyde et al., 2019). Interestingly, chains of hyaline globose to subglobose cells were repeatedly observed in specimens identified as $C$. caribense. To disentangle this conflict in morphological delimitation of C. caribense, we examined the holotype and confirmed the absence of these structures (Fig. 1B-C). Therefore, collections of this species in Goh et al. (1998) and Dayarathne et al. (2019) (collection MFLU15-3581, erroneously mentioned as the holotype) represent potential further records of $C$. thailandense worldwide. As $C$. dehongense is a later synonym of $C$. thailandense, the following synonymy is proposed:

Canalisporium thailandense Tibpromma \& K.D. Hyde, Fungal Diversity 93: 122 (2018).

Synonym: Canalisporium dehongense W. Dong et al., Fungal Diversity 96: 159 (2019).

In the most recent comprehensive treatment of the genus Canalisporium, Goh and Kuo (2021) accepted the recently introduced species $C$. krabiense, $C$. thailandense and $C$. dehongense. They also noted the obvious morphological similarity between $C$. thailandense and $C$. dehongense despite their distant phylogenetic position. However, given that both species are currently represented by a single specimen, our explanation for their similarity outlined above is more reasonable.

Specimen examined: Cuba, Isla de la Juventud (=Isla de Pinos), Cerro de San Juan, south-east of Santa Fe (now La Fe); on dead rotten branch, 22. Jan. 1981, V.

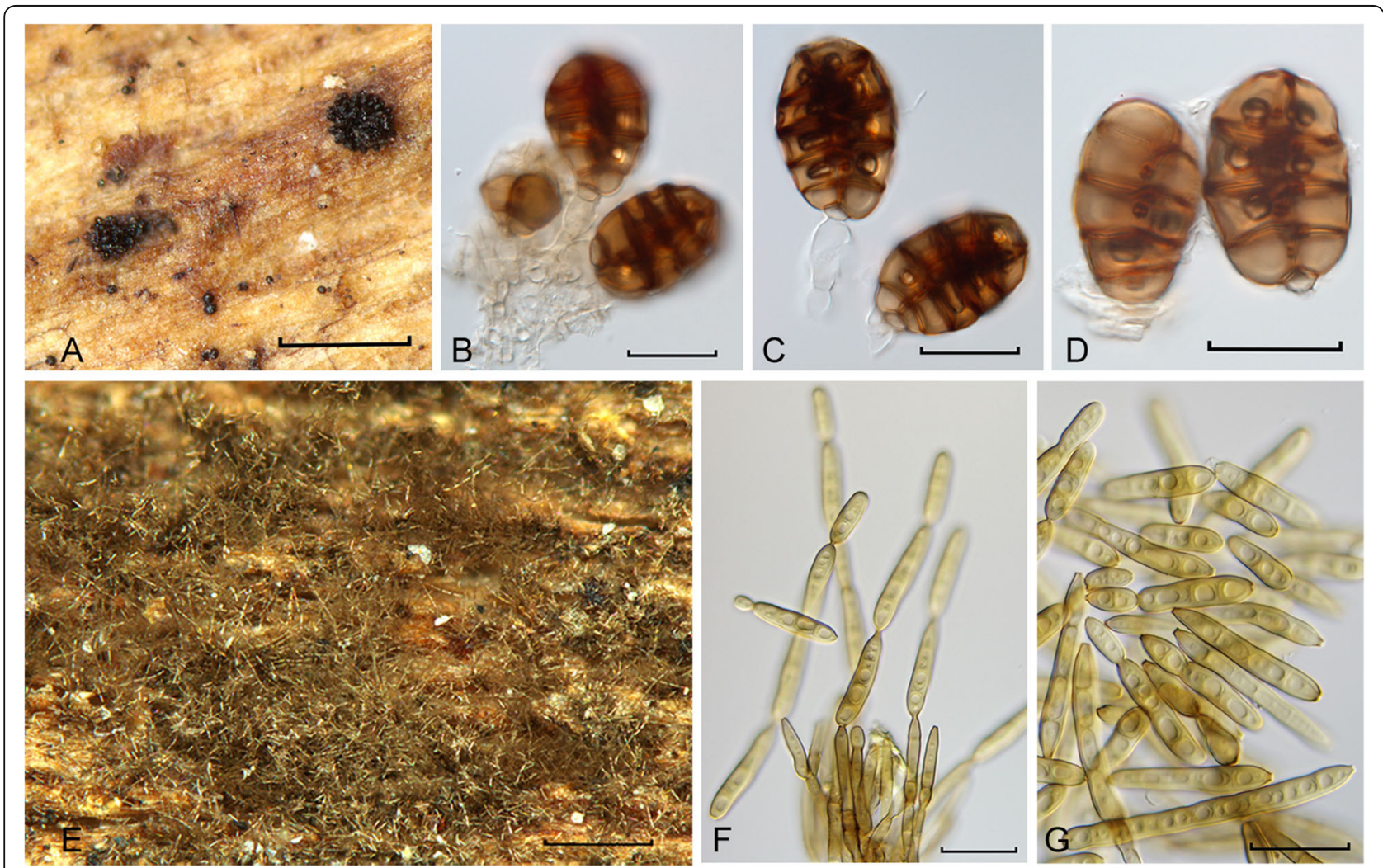

Fig. 1 Canalisporium caribense (PRM 831526, holotype). A. Two pulvinate sporodochia on natural substrate. B, C. Conidia still attached to a conidiogenous cell. D. Detached conidia showing septal pores. Sporidesmium tetracoilum (PRC 4681). E. Colony on natural substrate. F. Chains of conidia produced on conidiogenous cells. G. Conidia. Scale bars A, E =250 $\mu \mathrm{m}, \mathbf{B}-\mathbf{D}, \mathbf{F}, \mathbf{G}=20 \mu \mathrm{m}$ 
Holubová-Jechová (PRM 831526, holotype of Berkleasmium caribense Hol.-Jech.).

\section{Pseudohelminthosporium is a synonym of Neopodoconis}

The overemphasis on molecular data compounded with ignorance of old or recent mycological literature unnecessarily leads to further need for synonymies at the species level but also at the generic level. The recently introduced generic name Pseudohelminthosporium (Phukhamsakda et al. 2020) is a good example. Its type species, Ps. clematidis, described from a single specimen collected on dead stems of Clematis sikkimensis in Thailand, is obviously conspecific with the distinct and well documented species Exosporium ampullaceum (Ellis 1961). Its known distribution is pantropical and it has been recorded from several other Paleotropical countries so its presence in Thailand is not surprising. They both share a polytretic, sympodial conidiogenesis with cicatrized pores bearing dark and prominent scars. Conidia are obclavate, often rostrate, euseptate, sometimes smooth but usually verruculose, with a thick, black and protruding scars at the base and macronematous conidiophores emerging from a poorly developed stroma. The protologue of Ps. clematidis only mentions 3-5-euseptate conidia at maturity in contrast to Ellis (1961), who reports up to 27-septate conidia in E. ampullaceum. However, some of the illustrated conidia (Fig. 37j p. 69) are distinctly rostrate and show up to 12 septa in agreement with most descriptions of $E$. ampullaceum. Rifai (2008), on the other hand, typified the genus Neopodoconis based on E. ampullaceum. Therefore, the material representing Ps. clematidis serves to place this genus in Neomassarinaceae (Pleosporales). Its acceptance is further supported by the distant placement of the generic type of Exosporium, currently Helminthosporium tiliae (syn. Exosporium tiliae), in Massarinaceae (Voglmayr \& Jaklitsch, 2017). Accordingly, Pseudohelminthosporium is considered unnecessary and the following synonymy is proposed:

Neopodoconis ampullacea (Petch) Rifai, Reinwardtia 12(4): 278 (2008).

Basionym: Helminthosporium ampullaceum Petch, Ann. R. bot. Gdns Peradeniya 7(4): 319 (1922).

Synonyms: Exosporium ampullaceum (Petch) M.B. Ellis, Mycol. Pap. 82: 32 (1961).

Pseudohelminthosporium clematidis Phukhams. \& K.D. Hyde, Fungal Diversity 102: 59 (2020).

\section{Aquidictyomyces is a synonym of Biflagellospora}

Another recently introduced and putative novel genus, Aquidictyomyces (Dong et al. 2021), was based on an already described fungus. The generic type, A. appendiculatus, is clearly conspecific with the appendiculate species Biflagellospora papillata (Sivichai and Hywel-Jones
1999). Their conidia are identical in their distinct morphological appearance. They are composed of 8-9 cells, the main conidial body usually consisting of four cells with the two upper and larger ones having 4-8 distal 'protuberances' or 'horns' and bearing lateral arms which end in filiform, hyaline appendages up to $45 \mathrm{~mm}$ long. They also share a freshwater habitat and both fungi were collected from submerged wood in Thailand. The only difference between them is the polyblastic, sympodial conidiogenesis of $B$. papillata in contrast to the monoblastic, determinate conidiogenous cells observed in $A$. appendiculatus. However, the latter was based on the examination of a single specimen whereas $B$. papillata was described from two collections, which may better reflect the morphological and developmental variability of the fungus. Curiously, Fig. $30 \mathrm{~g}$ of the protologue of A. appendiculatus shows a different conidium consisting of two columns of cells with the distal ones ending in filiform appendages but lacking lateral arms or protuberances. This conidium corresponds to B. japonica, the generic type, originally described from Japan (Matsushima 1975) but also collected on submerged wood in different streams of Thailand (Sivichai and Hywel-Jones 1999). This contamination makes the phylogenetic placement of $A$. appendiculatus questionable and even despite the illustration of a germinating conidium (Fig. $30 \mathrm{~h}$ ), it is unclear which fungus it belongs to. Therefore, further specimens and molecular data are necessary to confirm the position of B. papillata within the family Annulatascaceae (Sordariomycetes). Based on the available evidence, Aquidictyomyces is also considered redundant and the following synonymy is proposed:

Biflagellospora papillata Sivichai \& Hywel-Jones, Mycol. Res. 103: 909 (1999).

Synonym: Aquidictyomyces appendiculatus W. Dong et al., Mycosphere 12(1): 68 (2021).

\section{Fusiconidium is a synonym of Camposporium}

Numerous genera of asexual Ascomycota are underrepresented by molecular data and "genotype first" identification inevitably leads to overlooking widely distributed and commonly occurring ones for which no sequences are available in public sequence databases. This is the case of Endophragmiella and the pleosporaceous genus Fusiconidium, recently described with two species ( $\mathrm{Li}$ et al. 2017). Its diagnostic features such as well differentiated conidiophores proliferating percurrently and euseptate, fusiform conidia that secede rhexolytically match those of Endophragmiella whereas Fusiconidium mackenziei, the generic type, is clearly conspecific with E. valdiviana. This cosmopolitan species was originally described over a century ago as Helminthosporium valdivianum (Spegazzini 1910). Subsequently, it has been recombined into different genera and illustrated several 
times in major taxonomic contributions such as Ellis (1976), Hughes (1979) and Wu and Zhuang (2005). Morphologically, both fungi share the presence of fusiform to ellipsoidal, 7-septate conidia, broadly truncate at base and bearing a distinct basal frill as a result of their identical rhexolytic conidiogenesis. Conidiogenous cells proliferate percurrently 1-4 times whereas conidiophore and conidial dimensions overlap well although $F$. mackenziei has shorter conidia, 38-40 $\mu \mathrm{m}$ long. However, they are within the variability range of $E$. valdiviana, which has conidia that are reported as $28-58 \mu \mathrm{m}$ long in Ellis (1963, 31-)34-42 $\mu \mathrm{m}$ in Hughes (1979). Moreover, the conidia of $F$. mackenziei show slight constrictions at the septa and this feature is also in agreement with the protologue of E. valdiviana (Spegazzini 1910). The only visible difference between them is that $F$. mackenziei apparently has echinulate conidia according to the protologue, although the original illustration (Fig. 1 p. 210) shows they are smooth.

Among species of Endophragmiella, only E. taxi and $E$. dimorphospora are represented in GenBank and their phylogenetic position is within Helminthosporiaceae (Sordariales) (Hernandez-Restrepo et al., 2017). Fusiconidium mackenziei, on the other hand, was placed within the distant Melanommataceae (Pleosporales). Therefore, F. mackenziei cannot be synonymized with $E$. valdiviana but a new combination should be provided. Hyde et al. (2020a) and Calabon et al. (2021) revealed that Fusiconidium grouped together with Camposporium but they considered these two genera distinct based on differences in conidiogenesis, conidial shape and the presence of apical appendages. From our point of view, however, there are numerous morphological similarities between them that justify their synonymy. Denticulate conidiogenous cells in Camposporium species are monoor polyblastic, for example in C. pellucidum or C. antennatum. The narrow, cylindrical denticles function as separating cells involved in the rhexolytic secession of conidia. They are analogous to the slender, cylindrical and monoblastic conidiogenous cells associated with the rhexolytic detachment process seen in $F$. aquaticum, the second species of the genus (Li et al., 2017). Moreover, the majority of Camposporium species has cylindrical conidia with one or more appendages. In contrast, some others have fusiform conidia, e.g. C. fusisporum (Whitton et al., 2002) while others lack appendages (e.g. C. ontariense, $C$. indicum), being reminiscent of those of Fusiconidium species. The only distinctive feature between these genera is the proliferation of the conidiogenous cells, enteroblastic percurrent in Fusiconidium vs sympodial in Camposporium. However, F. indicum (Pratibha, et al., 2017) has polyblastic conidiogenous cells with sympodial proliferations and slender, denticle-like separating cells suggesting that this character is not significant in separating them. Nevertheless, accepting the percurrently proliferating E. valdiviana in Fusiconidium would make Camposporium paraphyletic according to the most recent phylogenies of Hyde et al., (2020a) and Calabon et al. (2021). Therefore, we refrain from doing so and provide a new combination in Camposporium.

Camposporium valdivianum (Speg.) G. Delgado \& Koukol, comb. nov.

MycoBank MB838825.

Basionym: Helminthosporium valdivianum Speg., Revta Fac. Agron. Vet. Univ. nac. La Plata, Ser. 2 6(1): 192 (1910).

Synonyms: Endophragmiella valdiviana (Speg.) S. Hughes, N.Z. J. Bot. 17: 157 (1979).

Fusiconidium mackenziei Jun F. Li et al., Phytotaxa 308(2): 211 (2017).

Description: Spegazzini (1910).

The other species described by Li et al. (2017) and Pratibha et al. (2017), F. aquaticum and F. indicum, respectively, are with no doubt also members of Camposporium based on the morphological and phylogenetic evidence explained above. Since new combinations in both cases would result in illegitimate later homonyms for $C$. aquaticum and C. indicum, replacement names are proposed instead. A fourth species, F. lycopodiellae, was already transferred to Camposporium by Hyde et al. (2020a).

Camposporium verruculosum Koukol \& G. Delgado, nom. Nov.

MycoBank: MB 838826.

Replaced name: Fusiconidium aquaticum Z.L. Luo \& K.D. Hyde, Phytotaxa 308(2): 211 (2017).

Etymology: Named after the verruculose conidia, a unique characteristic in Camposporium.

Camposporium atypicum Koukol \& G. Delgado, nom. Nov.

MycoBank MB 838827.

Replaced name: Fusiconidium indicum J. Pratibha \& Prabhug., Phytotaxa 326(2): 113 (2017).

Etymology: Referring to the atypical morphology of the slightly curved conidia, unusual in Camposporium.

Lylea tetracoila is conspecific with Sporidesmium lignicola Another example of neglecting existing literature while introducing a novel ascomycetous fungus is the description of Sporidesmium lignicola (Luo et al. 2019). This is the first Sporidesmium species having linked asexual and sexual morphs and it was described from decaying wood submerged in a freshwater stream in China. The asexual morph of S. lignicola, however, shows a strong morphological similarity to Lylea tetracoila (Hughes 1952; Ellis 1976; Holubová-Jechová 1978). Species of the asexually typified genus Lylea, based on $L$. catenulata, are 
characterized by cylindrical or fusiform, distoseptate conidia in unbranched, acropetal chains that emerge from monoblastic, determinate conidiogenous cells (MorganJones, 1975; Xia et al., 2014). Both asexual S. lignicola and L. tetracoila form tufts of conidiophores similar in size, mostly 3-distoseptate, fusiform to cylindrical conidia $4.5-6.5 \mu \mathrm{m}$ wide and arranged in long, unbranched acropetal chains. The only difference between them is that the conidia of S. lignicola are slightly shorter and may reach $21-27 \mu \mathrm{m}$ long according to the protologue. However, a comparison with the scale bar in the original illustration (Fig. 20) indicates that conidia are longer and may reach $50 \mu \mathrm{m}$ in length in agreement with previous descriptions of $L$. tetracoila. This fungus has a long history of different generic placements since it was originally described within the now dubious genus Fusoma more than a century ago (Corda, 1838). A welldocumented species, it has been recorded and illustrated many times based on specimens collected throughout continental Europe (Holubová-Jechová 1978; Mel'nik 2000). It usually occurs on dead rotten wood, logs or fallen branches of different species of deciduous trees often growing on the ascomata or around the ostioles of pyrenomycetous fungi, mainly on the stromata of diatrypaceous ascomycetes. Alignment of unpublished ITS sequence from a Czech specimen (Fig. 1E-G) with strains of $L$. tetracoila deposited in CBS show they are identical. Similarly, alignment of LSU sequence with those belonging to the holotype and a paratype of S. lignicola was almost identical with only 3 out of $480 \mathrm{bps}$ different. Therefore, these two species should be considered conspecific. A new combination is proposed based on the available morphological and molecular evidence:

Sporidesmium tetracoilum (Corda) G. Delgado \& Koukol, comb. nov.

MycoBank MB 838828.

Basionym: Fusoma tetracoilum Corda, Icon. fung. 2: 5 (1838).

Synonyms: Lylea tetracoila (Corda) Hol.-Jech. Folia Geobot. Phytotax. 13: 437 (1978).

Sporidesmium lignicola Z.L. Luo et al., Fungal Diversity 99: 507 (2019).

Descriptions: Corda (1838) and Holubová-Jechová (1978).

Specimen examined: Czech Republic: Northern Bohemia, Bohemian Switzerland National Park, Mlýny above Vysoká Lípa, forest under the hilltop, on Fagus or Acer branch on the ground, 3 May 2018, K. Prášil 4/2018 (PRC 4681, ITS-LSU sequence GenBank OU413153).

\section{The genus Tricornispora and Eriosporella bambusicola}

The last cases we evaluate here are those of Eriosporella and the monotypic genus Tricornispora. Their phylogenetic placements were supposedly unknown until Dai et al. (2014) described E. bambusicola and provided a phylogenetic placement for Eriosporella within Capnodiales. However, the phylogenetic position of Eriosporella was known long before as E. calami, the generic type, was identified as the asexual morph produced in culture by Lachnum nipponicum, a member of Lachnaceae (Helotiales) (Haines \& Kaneko, 1984). The fungus that Dai et al. (2014) examined was undoubtedly conspecific with Tricornispora bambusae. Eriosporella bambusicola was isolated from a similar bambusicolous substrate and the conidiogenous cells are polyblastic which also matches the concept of Tricornispora rather than Eriosporella (van der Aa \& van Oorschot, 1985). Moreover, the conidial dimensions partially overlap. Conidial basal cells, for example, are 4.5-8.5 $\times 2.5-5 \mu \mathrm{m}$ vs. 7-12 $\times 5 \mu \mathrm{m}$ for E. bambusicola and T. bambusae, respectively, or nearly identical in the case of their conidial arms, $\quad 42.5-60 \times 3-5 \mu \mathrm{m}$ vs. $55-64 \times 4-6 \mu \mathrm{m} \quad$ (Bonar 1967; Dai et al. 2014). The phylogenetic placement among Capnodiales thus refers to T. bambusae. Van der Aa and van Oorschot (1985) also mentioned the similarity between the conidia of $T$. bambusae with those of Triglyphium bambusae, which have shorter arms (15$49 \times 3.3-5 \mu \mathrm{m}$ ) but still largely overlap. Considering also the identical type of conidioma and host, this species should be also treated as another synonym as follows:

Tricornispora bambusae Bonar, Mycologia 59: 597 (1967).

Synonyms: Eriosporella bambusicola D.Q. Dai et al., Cryptog. Mycol. 35: 45 (2014).

Triglyphium bambusae A.K. Roy, Sydowia 20: 203 (1968) ["1966”].

\section{CONCLUSIONS}

Considering the large number of already described asexual fungi in Ascomycota still lacking molecular data, careful examination of past and present taxonomic literature continues to play a critical role in describing new taxa. This is especially relevant for old or well documented taxa to avoid re-describing them as new. Gams (2016) wisely pointed out this problem as "the tedious search in the literature for possibly available names for their isolate." Although a full search of every relevant literature source and examination of all available fungal vouchers is not feasible (Hawksworth 2020), due diligence and conscious work from taxonomists in this regard is still strongly recommended. Fortunately, proper use of the many tools available nowadays including nomenclatural repositories and online accessible literature or databases opens up the possibility to keep the already huge taxonomic burden at a minimum.

Moreover, taxonomic decisions should be made responsibly following basic rules and recommendations provided regularly in informative and easy to follow 
articles (e.g. Aime et al. 2021). We would like to stress the importance of a thorough morphological study of multiple independent specimens leading to the recognition of interspecific variability in both molecular and phenotypic characteristics to produce a sound species hypothesis (Hawksworth 2020). Temptation to describe a taxonomic novelty based on a single gene or a single phenotypic difference should be overcome and robust support using multiple data should always be obtained. As in the case of a thorough morphological study, we also recommend using several molecular markers to provide stronger evidence for phylogenetic placement. Even those that are not ideal for phylogenetic analyses (e.g. due to excessive variability) should be amplified and published to allow a wider search in public databases and thus increase the probability of a match with an already published sequence. These rather simple steps will ensure the reliability of molecular data and obtained cultures and will provide an additional layer of quality control during fungal biodiversity studies.

\section{Acknowledgements}

We would like to thank Karel Prášil for allowing us to study the specimen of S. tetracoilum, Petra Seifertová for obtaining the DNA sequences from it and Markéta Šandová for arranging the loan from PRM.

\section{Adherence to national and international regulations} Not applicable.

\section{Authors' contributions}

OK conceived the study, obtained specimens and generated molecular data; both authors contributed equally to data interpretation and writing of the manuscript. The author(s) read and approved the final manuscript.

\section{Funding}

OK is supported by Institutional Support for Science and Research of the Ministry of Education, Youth and Sports of the Czech Republic.

\section{Availability of data and materials}

The only sequence obtained in this study was deposited in GenBank under Acc Nr. OU413153.

\section{Declarations}

Ethics approval and consent to participate

Not applicable.

\section{Consent for publication}

Not applicable.

\section{Competing interests}

The authors declare that they have no competing interests.

\section{Author details}

${ }^{1}$ Department of Botany, Faculty of Science, Charles University, Benátská 2, 12801 Prague, Czech Republic. ${ }^{2}$ EMLab P\&K Houston, 10900 Brittmoore Park Dr. Suite G, Houston, TX 77041, USA.

Received: 9 March 2021 Accepted: 23 July 2021

Published online: 23 September 2021

\section{References}

Aime MC, Miller AN, Aoki T, Bensch K, Cai L, Crous PW, Hawksworth DL, Hyde KD, Kirk PM, Lücking R, May TW, Malosso E, Redhead SA, Rossman AY, Stadler M, Thines M, Yurkov AM, Zhang N, Schoch CL (2021) How to publish a new fungal species, or name, version 3.0. IMA Fungus 12:11. https://doi.org/10.11 86/s43008-021-00063-1

Antonelli A, Fry C, Smith RJ, Simmonds MSJ, Kersey PJ, Pritchard HW et al (2020) State of the World's plants and Fungi 2020. Retrieved from: https://doi.org/1 $0.34885 / 172$

Bonar L (1967) Studies on Deuteromycetes. Mycologia 59(4):596-599. https://doi. org/10.2307/3757089

Calabon MS, Jones EBG, Boonmee S, Doilom M, LumyongS HKD (2021) Five novel freshwater Ascomycetes indicate high undiscovered diversity in lotic habitats in Thailand. Journal of Fungi 7(2):117. https://doi.org/10.3390/jof702 0117

Corda ACJ (1838) Icones fungorum hucusque cognitorum. Abbildungen von Pilzen und Schwaemmen (Vol. 2) Prag: JG Calve

Dai D-Q, Wijayawardene NN, Bhat DJ, Chukeatirote E, Zhao R, Wang Y et al (2014) The phylogenetic placement of Eriosporella bambusicola sp. nov. in Capnodiales. Cryptogamie, Mycologie 35(1):41-49. https://doi.org/10.7872/ crym.v35.iss1.2014.41

Dayarathne MC, Maharachchikumbura SSN, Jones EBG, Dong W, Devadatha B, Yang J, Ekanayaka AH, de Silva W, Sarma W, al-Sadi AM, Khongphinitbunjong K, Hyde KD, Zhao RL (2019) Phylogenetic revision of Savoryellaceae and evidence for its ranking as a subclass. Frontiers in Microbiology 10:840. https://doi.org/10.3389/fmicb.2019.00840

Delgado G, Koukol O, Heredia G, Piepenbring M (2020) Texas microfungi: Hermatomyces amphisporus (Pleosporales, Dothideomycetes) revisited. Czech Mycology 72(1):95-107. https://doi.org/10.33585/cmy.72107

Dong W, Hyde K, Jeewon R, Doilom M, Yu X, Wang G et al (2021) Towards a natural classification of annulatascaceae-like taxa II: introducing five new genera and eighteen new species from freshwater. Mycosphere 12(1):1-88

Ellis MB (1961) Dematiaceous hyphomycetes. III. Mycological Papers 82:55

Ellis MB (1963) Dematiaceous hyphomycetes. IV. Mycological Papers 87:42

Ellis MB (1976) More dematiaceous hyphomycetes. Commonwealth Mycological Institute, Kew

Forin N, Nigris S, Voyron S, Girlanda M, Vizzini A, Casadoro G, Baldan B (2018) Next generation sequencing of ancient fungal specimens: the case of the Saccardo mycological herbarium. Frontiers in Ecology and Evolution 6(129): 19. https://doi.org/10.3389/fevo.2018.00129

Gams W (2016) Are old taxa without living authenticated cultures losing their status? IMA Fungus 7(2):72-73

Goh TK, Ho WH, Hyde KD, Whitton SR, Umali TE (1998) New records and species of Canalisporium (Hyphomycetes): with a revision of the genus. Canadian Journal of Botany 76(1):142-152. https://doi.org/10.1139/b97-164

Goh TK, Kuo C-H (2021) Reflections on Canalisporium, with descriptions of new species and records from Taiwan. Mycological Progress 20(5):647-680. https://doi.org/10.1007/s11557-021-01689-6

Haines JH, Kaneko S (1984) A new foliicolous Lachnum from Japan. Transactions of the Mycological Society of Japan 25(3):237-242

Hawksworth DL (2020) Lessons from 50 years describing and classifying fungi. Kavaka 55:1-11. https://doi.org/10.36460/Kavaka/55/2020/1-11

Hernandez-Restrepo M, Gene J, Castaneda-Ruiz RF, Mena-Portales J, Crous PW, Guarro J (2017) Phylogeny of saprobic microfungi from southern Europe. Studies in Mycology 86:53-97. https://doi.org/10.1016/j.simyco.2017.05.002

Holubová-Jechová V (1978) Lignicolous hyphomycetes from Czechoslovakia. V: Septonema, Hormiactella and Lylea. Folia Geobotanica et Phytotaxonomica 13(4):421-442. https://doi.org/10.1007/BF02851944

Hughes SJ (1952) Four species of Septonema. Naturalist 840:7-12

Hughes SJ (1979) Relocation of species of Endophragmia auct. with notes on relevant generic names. New Zealand Journal of Botany 17(2):139-188. https://doi.org/10.1080/0028825X.1979.10426887

Hyde KD, Jeewon R, Chen Y.J, Bhunjun CS, Calabon MS, Jiang H-B et al (2020b) The numbers of fungi: is the descriptive curve flattening? Fungal Diversity 103(1):219-271. https://doi.org/10.1007/s13225-020-00458-2

Hyde KD, Dong Y, Phookamsak R, Jeewon R, Bhat DJ, Jones EBG, Liu NG, Abeywickrama PD, Mapook A, Wei D, Perera RH, Manawasinghe IS, Pem D, Bundhun D, Karunarathna A, Ekanayaka AH, Bao DF, Li J, Samarakoon MC, Chaiwan N, Lin CG, Phutthacharoen K, Zhang SN, Senanayake IC, Goonasekara ID, Thambugala KM, Phukhamsakda C, Tennakoon DS, Jiang HB, Yang J, Zeng M, Huanraluek N, Liu JK(J), Wijesinghe SN, Tian Q, Tibpromma S, Brahmanage RS, Boonmee S, Huang SK, Thiyagaraja V, Lu YZ, Jayawardena RS, Dong W, Yang EF, Singh SK, Singh SM, Rana S, Lad SS, Anand G, Devadatha B, Niranjan M, Sarma W, Liimatainen K, Aguirre-Hudson B, Niskanen T, Overall A, Alvarenga RLM, Gibertoni TB, Pfliegler WP, Horváth E, 
Imre A, Alves AL, da Silva Santos AC, Tiago PV, Bulgakov TS, Wanasinghe DN, Bahkali AH, Doilom M, Elgorban AM, Maharachchikumbura SSN, Rajeshkumar KC, Haelewaters D, Mortimer PE, Zhao Q, Lumyong S, Xu J, Sheng J (2020a) Fungal diversity notes 1151-1276: taxonomic and phylogenetic contributions on genera and species of fungal taxa. Fungal Diversity 100(1):5-277. https:// doi.org/10.1007/s13225-020-00439-5

Hyde KD, Norphanphoun C, Chen J, Dissanayake AJ, Doilom M, Hongsanan S, Jayawardena RS, Jeewon R, Perera RH, Thongbai B, Wanasinghe DN, Wisitrassameewong K, Tibpromma S, Stadler M (2018) Thailand's amazing diversity: up to $96 \%$ of fungi in northern Thailand may be novel. Fungal Diversity 93(1):215-239. https://doi.org/10.1007/s13225-018-0415-7

Hyde KD, Tennakoon DS, Jeewon R, Bhat DJ, Maharachchikumbura SN, Rossi W et al (2019) Fungal diversity notes 1036-1150: taxonomic and phylogenetic contributions on genera and species of fungal taxa. Fungal Diversity 96(1):1242. https://doi.org/10.1007/s13225-019-00429-2

Koukol O, Delgado G (2019) Do not forget Africa - revision of fungarium collections at Kew revealed a new species of Hermatomyces (Hermatomycetaceae, Pleosporales). Nova Hedwigia 109(3-4):413-423. https://doi.org/10.1127/nova hedwigia/2019/0559

Koukol O, Delgado G, Hofmann TA, Piepenbring M (2018) Panama, a hot spot for Hermatomyces (Hermatomycetaceae, Pleosporales) with five new species, and a critical synopsis of the genus. IMA Fungus 9(1):107-141. https://doi. org/10.5598/imafungus.2018.09.01.08

Koukol O, Halasů V, Janošík L, Mlčoch P, Polhorský A, Šandová M, Zíbarová L (2020) Citizen science facilitates phylogenetic placement of old species of non-lichenised Pezizomycotina based on newly collected material. Czech Mycology 72(2):263-280. https://doi.org/10.33585/cmy.72207

Li J, Jeewon R, Luo Z, Phookamsak R, Bhat J, Mapook A et al (2017) Morphological characterization and DNA based taxonomy of Fusiconidium gen. nov. with two novel taxa within Melanommataceae (Pleosporales). Phytotaxa 308(2):206-218. https://doi.org/10.11646/phytotaxa.308.2.2

Lücking R, Aime MC, Robbertse B, Miller AN, Ariyawansa HA, Aoki T, Cardinali G, Crous PW, Druzhinina IS, Geiser DM, Hawksworth DL, Hyde KD, Irinyi L, Jeewon R, Johnston PR, Kirk PM, Malosso E, May TW, Meyer W, Öpik M, Robert V, Stadler M, Thines M, Vu D, Yurkov AM, Zhang N, Schoch CL (2020) Unambiguous identification of fungi: where do we stand and how accurate and precise is fungal DNA barcoding? IMA Fungus 11(1):1-32, 14, https://doi. org/10.1186/s43008-020-00033-z

Luo Z-L, Hyde KD, Liu J-K, Maharachchikumbura SSN, Jeewon R, Bao D-F et al (2019) Freshwater Sordariomycetes. Fungal Diversity 99(1):451-660. https:// doi.org/10.1007/s13225-019-00438-1

Matsushima T (1975) Icones microfungorum: a Matsushima lectorum. Kobe

Mel'nik V (2000) Opredelitel' gribov Rossii. Klass Hyphomycetes. Vyp. 1. SeM Dematiaceae. St. Petersburg: Nauka

Morgan-Jones G (1975) Notes on Hyphomycetes VIII. Lylea, a new genus. Mycotaxon 3(1):129-132

Phukhamsakda C, McKenzie EHC, Phillips JL, Jones GEB, Jayarama Bhat D, Stadler $M$ et al (2020) Microfungi associated with Clematis (Ranunculaceae) with an integrated approach to delimiting species boundaries. Fungal Diversity 102(1):1-203. https://doi.org/10.1007/s13225-020-00448-4

Pratibha J, Ashish P. Mao AA (2017) Fusiconidium indicum (Melanommataceae) a novel species of asexual Ascomycetes. Phytotaxa 326(2):108-114. https://doi. org/10.11646/phytotaxa.326.2.2

Rifai MA (2008) Another note on Podoconis megasperma Boedijn (Hyphomycetes). Reinwardtia 12(4):277-279

Sivichai S, Hywel-Jones N (1999) Biflagellospora (aero-aquatic hyphomycetes) from submerged wood in Thailand. Mycological Research 103(7):908-914 https://doi.org/10.1017/S0953756298007928

Spegazzini C (1910) Ramillete de hongos chilenos. Revista de la Facultad de Agronomía, La Plata 6(1):1-205

Tibpromma S, Hyde KD, McKenzie EHC, Bhat DJ, Phillips AJL, Wanasinghe DN et al (2018) Fungal diversity notes 840-928: micro-fungi associated with Pandanaceae. Fungal Diversity 93(1):1-160. https://doi.org/10.1007/s13225-01 8-0408-6

van der Aa HA, van Oorschot CAN (1985) A redescription of some genera with staurospores. Persoonia 12(4):415-425

Van Vooren N, Vega M (2018) A post-publication review of Ekanayaka et al. (2018) on Pezizomycetes

Voglmayr H, Jaklitsch WM (2017) Corynespora, Exosporium and Helminthosporium revisited - new species and generic reclassification. Studies Mycol 87:43-76. https://doi.org/10.1016/j.simyco.2017.05.001
Whitton S, McKenzie EHC, Hyde KD (2002) Microfungi on the Pandanaceae: two new species of Camposporium and key to the genus. Fungal Diversity 11: $177-187$

Wijayawardene NN, Hyde KD, Lumbsch HT, Liu JK, Maharachchikumbura SN, Ekanayaka AH et al (2018) Outline of Ascomycota: 2017. Fungal Diversity 88(1):167-263. https://doi.org/10.1007/s13225-018-0394-8

Wu W, Zhuang W (2005) Sporidesmium, Endophragmiella and related genera from China (Vol. 15): Fungal Diversity Press

Xia J-W, Ma Y-R, Zhang X-G (2014) New species of Corynesporopsis and Lylea from China. Sydowia 66(2):241-248

\section{Publisher's Note}

Springer Nature remains neutral with regard to jurisdictional claims in published maps and institutional affiliations.
Ready to submit your research? Choose BMC and benefit from:

- fast, convenient online submission

- thorough peer review by experienced researchers in your field

- rapid publication on acceptance

- support for research data, including large and complex data types

- gold Open Access which fosters wider collaboration and increased citations

- maximum visibility for your research: over $100 \mathrm{M}$ website views per year

At BMC, research is always in progress.

Learn more biomedcentral.com/submissions 